\title{
Design and Build Disaster Emergency Response Systems Using Firebase Cloud Messaging Based on Android and SMS Gateway
}

\author{
Tri Ferga Prasetyo ${ }^{\mathrm{a}^{*}}$, Rohmat ${ }^{\mathrm{a}}$, Dadan Zalilluddin ${ }^{\mathrm{a}}$ \\ ${ }^{a}$ Informatics Study Program, Faculty of Engineering, Majalengka University \\ Itriferga.prasetyo@gmail.com*,2 brokenwings.c@gmail.com, ${ }^{3}$ dadanzuu@gmail.com \\ * corresponding author
}

\begin{abstract}
Design and implementation emergency response system using firebase cloud messaging android based and sms gateway is a disaster notification information system using mobile android based media by utilizing support from firebase cloud message service and sms gateway. This study aims to assist BPBD Majalengka District in improving the effectiveness, accuracy, and speed of the process of delivering disaster information to the public. Applications use cross-platform messaging through firebase clouds that are able to perform real-time notification reporting to users with details or formatting of text, images, or map coordinates. This research uses Agile Method Development system with Rational Unified Process and software used in making this application is using Android Studio 2.3.2 and PHP programming language.
\end{abstract}

Keywords:

Firebase Cloud Messaging

Regional Disaster

Management Agency

(BPBD)

Agile Method Development

\section{Introduction}

At present the development of information technology has undergone considerable changes, the development of technology certainly cannot be separated from innovations created by humans (McLuhan, Marshall. 2006 [1]). Along with the rapid progress of information technology, information is very important in carrying out a job and activity. Various aspects of life are greatly helped by the advancement of information technology, this is felt by various parties who begin to feel that information technology is a difficult thing to separate from daily work. One technology that is very inherent in the lives of Indonesian people is Mobile device technology.

Currently, cellular provider support has spread to almost all regions in Indonesia. This is a great opportunity to utilize mobile device technology in solving various public problems, including in the field of disaster management or disaster management. Mobile or mobility can be defined as the ability to be able to move or be moved easily (V. Lee et al, 2004 [2]). In the context of disaster management, related entities can be assisted with a mobile device and a mobile application. With a system connected to the control center server, applications and mobile devices can be an accurate, effective, and realtime source of information to support the process of sending disaster data.

Disaster is an event caused by nature or because of human activities that can occur suddenly and slowly, which causes loss of human life, damage to property and environment, and beyond the ability and resources of the community to overcome them (BNBP, 2010 [3 ]). Landslides are one of the natural disasters that often hit the tropics or wetlands. The damage caused by mass movements is not only direct damage such as damage to public facilities, agricultural land, or human casualties, but also indirect damage that paralyzes development activities and economic activities in the disaster area and its surroundings.

The Center for Volcanology and Geological Disaster Mitigation (PVMBG) of the Ministry of Energy and Mineral Resources states that West Java is a region that has a high potential of experiencing a landslide. There are around 22 regencies / cities in West Java that have the potential to experience land movement and have a high level of vulnerability to landslides, and Majalengka Regency is one of the regions or districts prone to landslides. Mentioned by the Head of the Regional Disaster Management Agency (BPBD) of Majalengka Regency H. Toto Sumianto through Rena's 
logistics services, based on collected data, from the beginning of January 2017 to the present there have been at least 9 natural disasters in the form of landslides, abrasions and flooding in the Malausma District, Lemah Sugih, Bantarujeg, Argapura, Maja, and Majalengka Districts. In general, disasters that occur are dominated by landslides and the cause is thought to be strongly caused by high rainfall levels. Disaster management needs to be supported by the availability of accurate data and information. According to the BPBD PUSDALOPS Majalengka A. Bicky Amanatullah in the interview session the research stated that, "At present, the process of delivering data on disasters available in Majalengka Regency has not been well integrated, where disaster data and information formats are still diverse, and community support for this disaster very important role in supporting the process of delivering information. For this reason, a reference is needed as a guideline for effective, fast and accurate management of data and information on disaster management so that the community and BPBD can be connected to each other well.

Based on the explanation above, the researcher concluded that the BPBD of Majalengka Regency needed an early warning system (Early Warning System) based on android mobile applications to support and assist BPBD in Majalengka Regency in improving the process of delivering disaster information or disaster management to the community to be more effective, faster, and accurate. An early warning system is an order to deliver information on the results of predictions to a threat to the community before the occurrence of an event that can pose a risk. EWS aims to provide a warning so that recipients of information can immediately be prepared and act according to the right conditions, situations and times. The main principle in EWS is to provide information quickly, accurately, on target, easily accepted, easily understood, trusted, and sustainable by decision makers (the community).

Therefore, this research is focused on designing and building an early warning system to assist BPBD in providing disaster information, especially in Majalengka.

\section{Method}

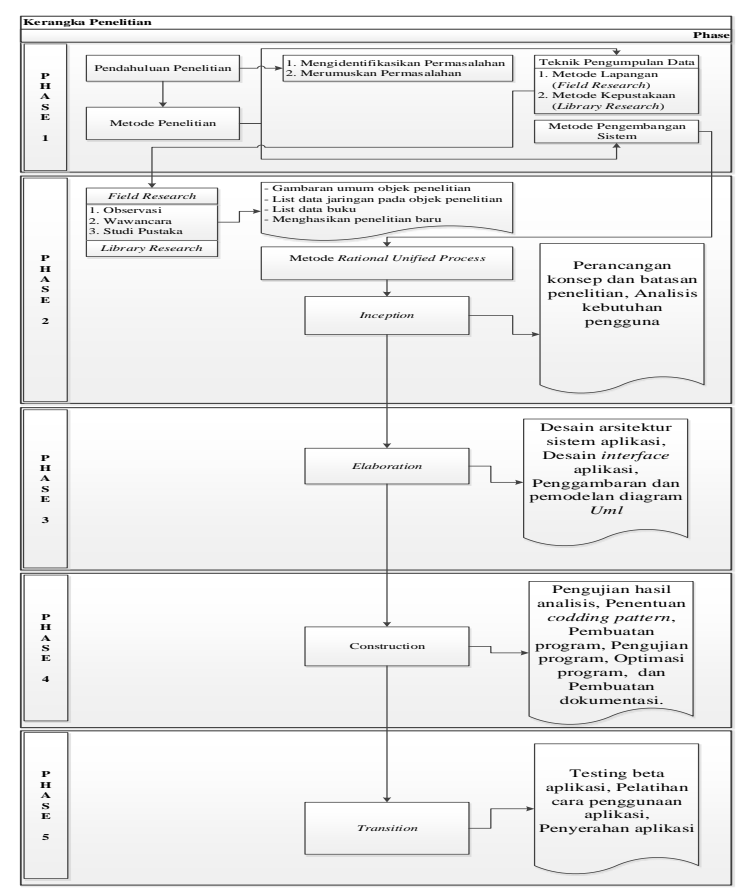

Fig. 1. Research Framework

In this study researchers used the Rational Unified Process (RUP) research method where in this method there are 4 phases or stages that must be done. The stages are as follows:

\section{Inception}

At this stage the researcher defines the boundaries of activities, analyzes the needs of the user, performs the initial design of the software, modeling UML diagrams (use case diagrams), and making documentation. 


\section{Elaboration}

The stage to complete the design based on the results of the analysis in the inception stage. Activities carried out at this stage include the creation of a subsystem architecture design, system component design, data format design (communication protocol), interface design, display flow map design, determination of the design pattern used, UML diagram modeling ( activity diagram, class) and documentation.

\section{Contruction}

Stage to implement the results and test the results of the implementation. In the initial stages of construction, a re-examination of the results of analysis and design is carried out, if the design made is in accordance with the system analysis, then the implementation with the java programming language can be done. Activities carried out at this stage include testing the results of analysis and design, data collection of complete implementation needs (guided by identification of needs at the analysis stage), determination of the codding pattern used, programming, testing, program optimization, data collection on various possibilities for further development / improvement, and making documentation.

\section{Transition}

The stage to submit the system to the consumer (roll-out), which generally includes the implementation of training for users and application beta testing on user expectations.

\section{Result and Discussion}

Designing an application system Designing the Implementation of Disaster Emergency Response Systems Using Firebase Cloud Messaging Based on Android and SMS Gateway

Use case system diagram for Android

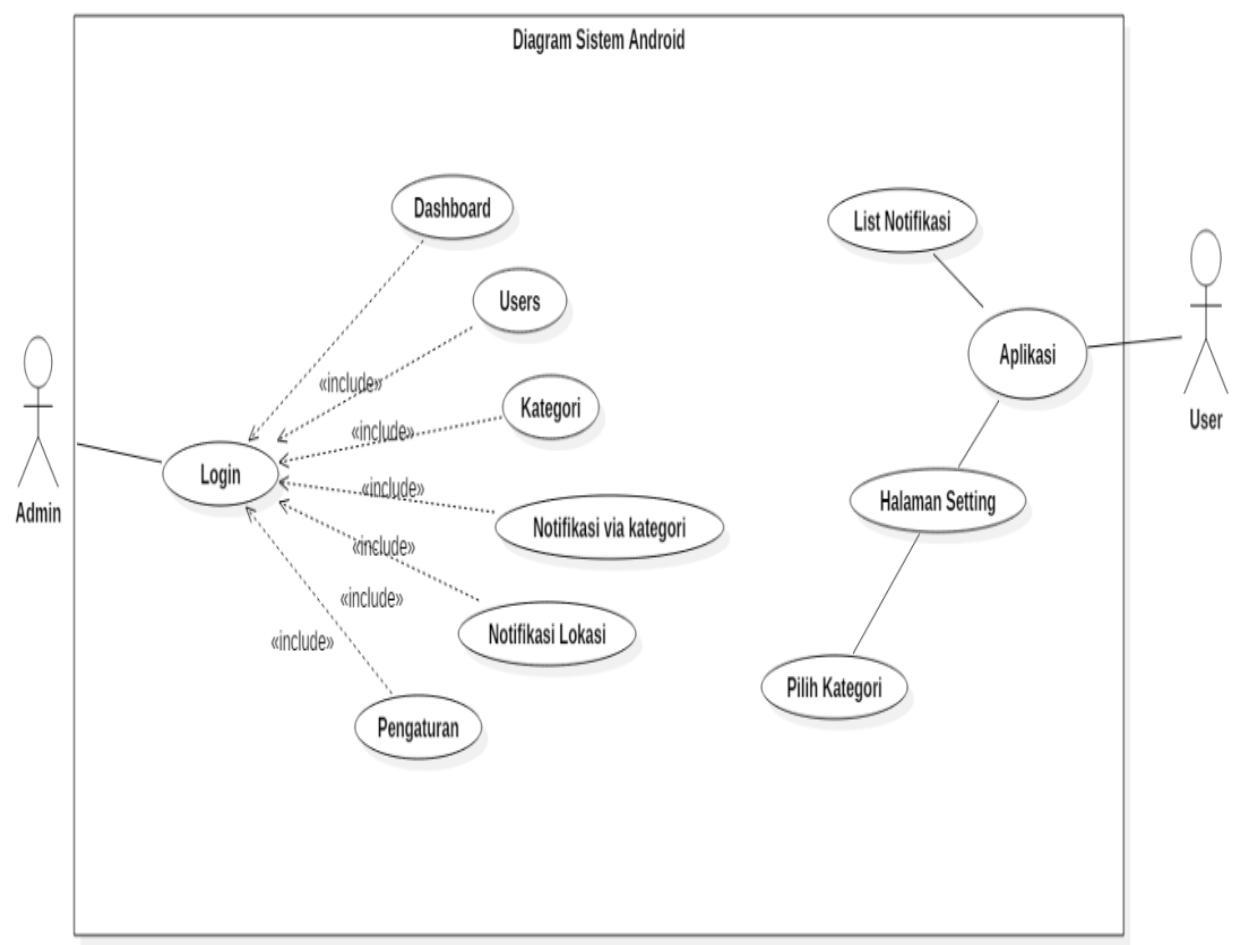

Fig. 2. Use Case Diagram of the Android System 


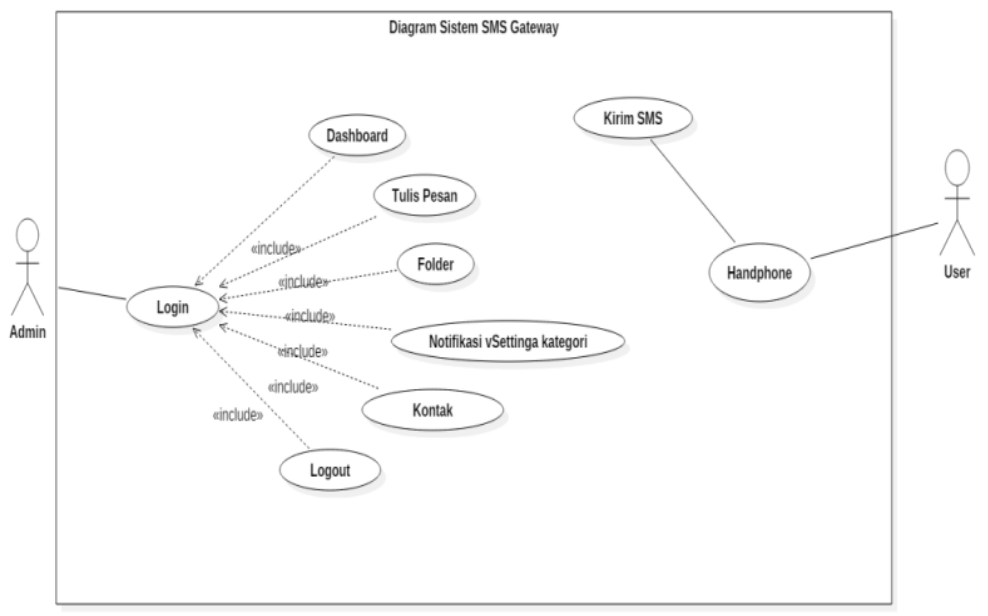

Fig. 3.. Use Case Diagram SMS gateway system

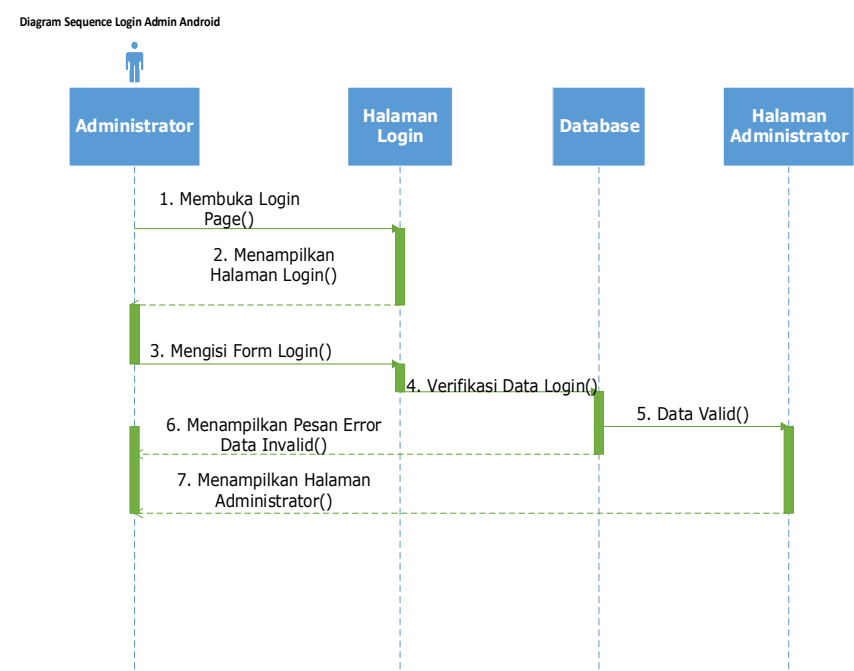

Fig. 4. Sequence Diagram of the Android Administrator Login

Figure 4 is the Sequence administrator login diagram. In the login sequence diagram process, the administrator inputs the username and password to be able to enter and access the administrator page. The username and password on the login form will be validated by the system then the system will direct the administrator to the administrator page if the username and password match the data in the system database.

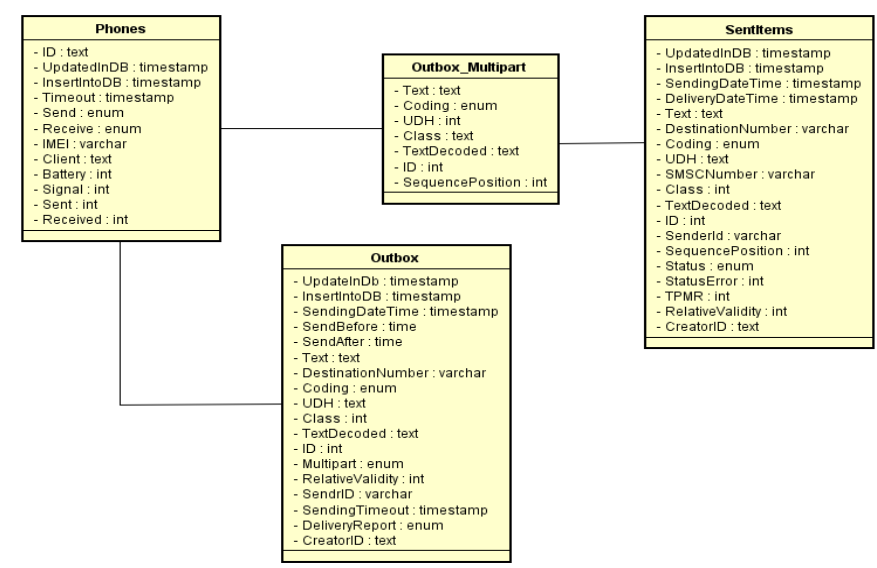

Fig. 5. Class Gateway SMS System Diagram 
The following sections are the results and implementation of the application of the Design of Disaster Emergency Response System Implementation Using Firebase Cloud Messaging Based on Android and Sms Gateway, which consists of an explanation of supporting applications and the results of checking or testing applications that have been made, where testing of these applications is done using the Black Box and White Box Testing testing

a. System Requirements Specifications

The following are the supporting devices needed to run the application.

Windows 7 operating system, or more;

HP 431 Core i3 laptop;

2 Gb RAM memory;

LG G4 Smartphone Lolipop Version 5.0;

Internet browser (Google Chrome);

Web Server Service (Hosting)

USB Cable Smartphone

b. Black Box Testing

It is a test that is performed only observing the results through execution of test data and functional checking of the software. The test samples are as follows:

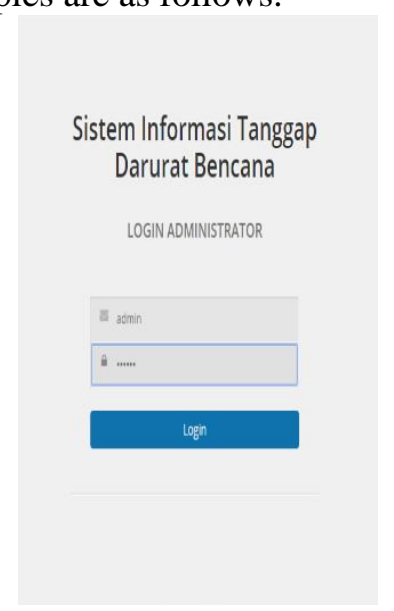

Fig. 6. Android Administrator Login

Table 1. Testing Android Login

\begin{tabular}{|c|c|c|c|}
\hline No & Testing & Results & Explanation \\
\hline 1 & $\begin{array}{l}\text { Fill in the } \\
\text { email address } \\
\text { and password } \\
\text { correctly then } \\
\text { click login }\end{array}$ & $\begin{array}{l}\text { Display the } \\
\text { administrator } \\
\text { page }\end{array}$ & success \\
\hline 2 & $\begin{array}{l}\text { Fill in the } \\
\text { wrong email } \\
\text { address and } \\
\text { password then } \\
\text { click login }\end{array}$ & $\begin{array}{l}\text { A failed login } \\
\text { warning } \\
\text { message } \\
\text { appears and } \\
\text { asks to fill in } \\
\text { the email } \\
\text { address and } \\
\text { password } \\
\text { again }\end{array}$ & success \\
\hline
\end{tabular}




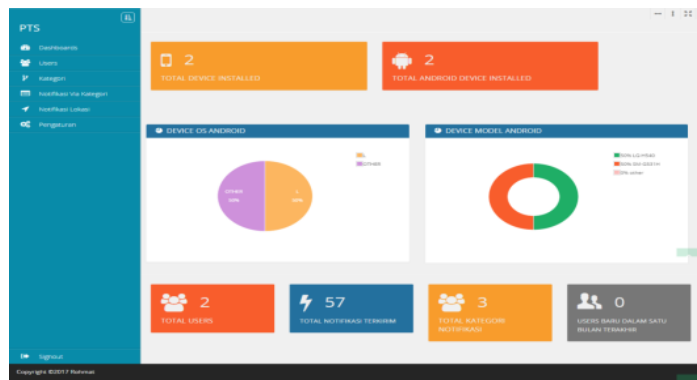

Fig. 7. Android Administrator Page

Table 2. Testing Administrator Android Page

\begin{tabular}{|c|c|c|c|}
\hline No & Testing & Results & Explanation \\
\hline 1 & $\begin{array}{c}\text { Klik } \\
\text { Dashboard }\end{array}$ & $\begin{array}{l}\text { Displays the Dashboard } \\
\text { page that contains the } \\
\text { menu icon, total device } \\
\text { installed, android os } \\
\text { device, android device } \\
\text { model, users, total } \\
\text { notifications, total sent } \\
\text { notification categories, } \\
\text { and total users in the } \\
\text { past month }\end{array}$ & success \\
\hline 2 & Klik User & $\begin{array}{l}\text { Displays information } \\
\text { and list of users who } \\
\text { have installed the } \\
\text { application }\end{array}$ & success \\
\hline 3 & $\begin{array}{l}\text { Klik } \\
\text { Kategori }\end{array}$ & $\begin{array}{l}\text { Display the form added } \\
\text { categories and a list of } \\
\text { categories that have } \\
\text { been created or added }\end{array}$ & success \\
\hline 4 & $\begin{array}{l}\text { Klik } \\
\text { Notification } \\
\text { Via } \\
\text { Kategori }\end{array}$ & $\begin{array}{l}\text { Displays a page for } \\
\text { administrators to send } \\
\text { notifications in bulk to } \\
\text { users based on } \\
\text { categories }\end{array}$ & success \\
\hline 5 & $\begin{array}{l}\text { Klik } \\
\text { Notification } \\
\text { Lokasi }\end{array}$ & $\begin{array}{l}\text { Displays a page for } \\
\text { administrators to send } \\
\text { notifications to users } \\
\text { based on the location } \\
\text { chosen by the } \\
\text { administrator }\end{array}$ & success \\
\hline 6 & Klik Setting & $\begin{array}{l}\text { Displays the form to } \\
\text { change the } \\
\text { administrator password } \\
\text { and change the fire key } \\
\text { form }\end{array}$ & success \\
\hline 7 & Klik Signout & $\begin{array}{l}\text { Exit the Administrator } \\
\text { Page }\end{array}$ & success \\
\hline
\end{tabular}




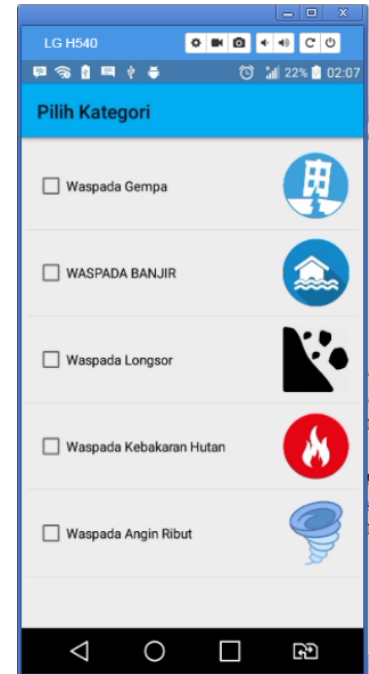

Fig. 8. Android Notification Category

Table 3. Testing Of Android Application Notification Categories

\begin{tabular}{llll}
\hline No & Testing & \multicolumn{1}{c}{ Results } & Explanation \\
& & & \\
\hline 1 & Check / & Display the & success \\
& Check & Checklist / & \\
& Selected & Not Checked & \\
& Categories & and & \\
& & Notification \\
& of the \\
& Checked \\
& Category \\
& Successfully \\
& Filtered \\
& \\
&
\end{tabular}

c. White Box Testing

Is a desin test case that uses a procedural design control structure to obtain a test case. In this whitebox testing is not done on the whole program as a whole, but it is done only on certain coding functions that are sampled only.

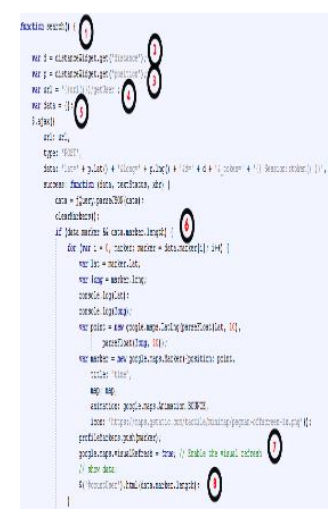

Fig. 9. The coding is used as a white box testing testing sample; 


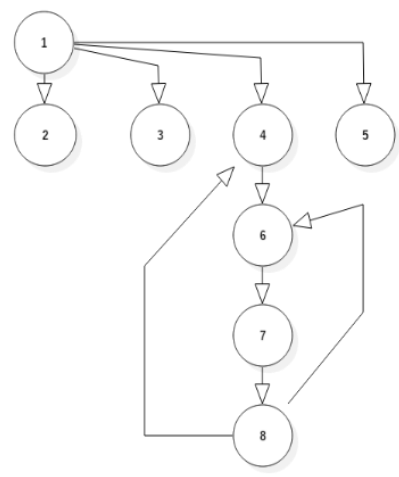

Fig. 10. Independent Graph of User Locations Path

Figure 10. is a graph of flow looking for a user location where Siklomatis Compexity (Quantitative measurement of the logical complexity of a program) from the flow chart above can be obtained by the amount of cyclomatic complexity with calculations:

$$
\mathrm{V}(\mathrm{G})=\mathrm{E}-\mathrm{N}+2(\mathrm{i})
$$

That is :

$\mathrm{E}=$ Number of edges of the flow chart that is indicated by an arrow

$\mathrm{N}=$ Number of flow graph nodes that are indicated by a circle image

So that the complexity is cyclical:

$$
\mathrm{V}(\mathrm{G})=9-8+2=3 \text { (ii) }
$$

Based on the results of the calculation of cyclomatic complexity, the Base Sets generated from the independent lines are linearly as follows:
a. 1 - 2 - $3-4-5$
b. $1-4-6-7-8-4$
c. $1-4-6-7-8-6$

The Base Set information above shows that when the application is run it appears that one of the Base Sets produced is $1-4-6-7-8-4$, and it appears that the node has been executed at least once. Likewise with the other two Base Sets. So based on these provisions in terms of software feasibility, this system has met the requirements.

\section{Conclusion}

The conclusions that can be taken in the study are as follows:

1. This mobile application has the concept of an Early Warning System related to disaster issues in Majalengka Regency

2. With this application, the public can receive information or disaster warnings from Majalengka BPBD accurately and in detail through their smarthphone;

3. By using the push notification from the firebase, the BPBD Majalengka cloud messaging can deliver disaster information in real time with secure media storage (cloudbase).

\section{Acknowledgment}

The Writers' Team would like to thank the entire community of Majalengka University for supporting this research. 


\section{References}

[1] McLuhan, Marshall. The Medium is the Message. United Kingdom : Blackwell, 2006.

[2] V. Lee, H. Schneider, dan R. Shell, "Mobile Application, Architecture Design \& Development", Prentice Hall, 2004.

[3] BNPB Nomor 5 Tahun 2010 tentang Rencana Aksi Nasional Pengurangan Resiko Bencana. Jakarta.

[4] Jogiyanto HM. Analisa \& Desain Sistem Informasi : Pendekatan Terstruktur Teori dan Praktek Aplikasi Bisnis. Yogyakarta, Andi. 2005.

[5] Silberschatz, A. dkk. Database System Concepts, 4th Edition, New York : McGraw-Hill, 200

[6] Peraturan Kepala Badan Nasional Penanggulangan Bencana Nomor 10 Tahun 2008 tentang Penanggulangan Bencana alam. Jakarta.

[7] Undang-undang No 24 tahun 2007 tentang Penanggulangan Bencana alam. Jakarta.

[8] Firebase Realtime Database.(t.thn). situs resmi Firebase : https://firebase.google.com/docs/database/. Tanggal Akses 01 Juni 2017.

[9] Hermawan S, Stephanus. Mudah Membuat Aplikasi Android.Yogyakarta : Andi Offset, 2011.

[10] Prabowo Pudji Widodo Herawati. Menggunakan UML Secara Luas Digunakan Untuk Memodelkan Berorientasi Objek. Bandung : Informatika. 2011 